\title{
LITHOSTRATIGRAPHY, PETROGRAPHY AND DIAGENESIS OF UM BOGMA FORMATION IN TALET SELEIM AREA, SOUTHWESTERN SINAI, EGYPT
}

\author{
Abdel-Maksoud, Y. G. ${ }^{1}$ Abu-Zeid, M. M. ${ }^{1}$, El Aassy, I. E. ${ }^{2}$, Baghddady, A. R. ${ }^{1}$ \\ 1Geology Department, Faculty of Science, Ain Shams University, P.O. Box 11566, Cairo, Egypt \\ 2 Nuclear Materials Authority, P.O. Box 530, Maadi, Cairo, Egypt
}

\begin{abstract}
A detailed geologic map of Talet Seleim area was prepared. Ten stratigraphic sections of the Lower Carboniferous Um Bogma Formation were studied and used to construct a composite section and panel diagram

The Um Bogma Formation could be subdivided into a lower siltstone-dolostone member, a middle siltstone-mudstone-dolostone member and an upper dolostone member. These rock units have unconformable contacts and show marked lateral variations in thickness and minor changes in lithology. The argillaceous rocks are texturally classified as mudstone, sandy mudstone, siltstone and sandy siltstone (in decreasing order of abundance). The carbonates, on the other hand, are classified as dolosparite and dolomitized intra-biosparite. The rocks display several primary sedimentary structures; the most common of which are various types of bedding, lamination and biogenic features. Also, the succession is affected by joints, faults and small scale folds and contains gypsum veins and clastic dykes.

Diagenesis played a major role in modifying the original textural and, especially, compositional characteristics of the rocks. It involved compaction, cementation, replacement, alteration and dissolution. The extent of each of these processes varied markedly among the different lithologic types and rock units as well as the locations in Talet Seleim area. Most of the post-depositional processes commenced during the mesogenetic phase of diagenesis and became more profound during epigenesis.
\end{abstract}

Keywords: Southwestern Sinai, Talet Seleim, Um Bogma Formation, lithostratigraphy, petrography, diagenesis, argillaceous rocks, carbonates

\section{INTRODUCTION}

The Paleozoic succession in southwestern Sinai was subdivided by several authors into a number of rock units that were given different names (e.g.; Barron, 1907; Ball, 1916; Omara and Schultz, 1965; Weissbrod, 1969; Soliman and El Fetouh, 1969; El Shahat and Kora, 1986 and Kora et al., 1994). The term "Um Bogma Formation” was first used by Said (1962) for the Carboniferous carbonates and underlying clastics in Um Bogma area to replace the term "Um Bogma Series" of Kostandi (1959). The formation is unconformably underlain by the Cambro-Ordivician Adediya Formation and overlain by the Lower Carboniferous Abu Thora Formation. An Early Carboniferous age for the Um Bogma Formation is accepted by most authors based on its fossil content. The thickness of the formation varies markedly from a maximum of $\sim 43 \mathrm{~m}$ in its type locality at $\mathrm{W}$. Khaboba in the north to a minimum of $\sim 3 \mathrm{~m}$ in G. Adediya and G. Ghorabi to the south.

The lithologic characteristics of Um Bogma Formation in several localities were studied by numerous workers (e.g.; Weissbrod, 1969 and 1980; Omara, 1971; El Shazly et al., 1974; Kora, 1984 and El Fiky, 1988). They subdivided the formation into three members which, however, were given different names as a result of the marked lateral variations in lithology. Recently, Abu-Zeid et al. (2018) carried out comprehensive field and petrographic studies on this formation in Gabel Um Hamd in southwestern Sinai. They subdivided it into a lower siltstone-Fe, Mn ore member, a middle siltstone-mudstone member and an upper dolostone-dolomitic limestone member. Abu-Zeid et al. (op.cit.) reported that the rocks consist of a 